\title{
Project-Based Learning to Promote Effective Learning in Biotechnology Courses
}

\author{
Farahnaz Movahedzadeh, Ryan Patwell, Jenna E. Rieker, and Trinidad Gonzalez \\ Department of Biological Sciences, Harold Washington College, 30 East Lake Street, Chicago, IL 60601, USA \\ Correspondence should be addressed to Farahnaz Movahedzadeh, fmovahedzadeh@ccc.edu
}

Received 19 March 2012; Accepted 23 May 2012

Academic Editor: Annemie Desoete

Copyright ( $) 2012$ Farahnaz Movahedzadeh et al. This is an open access article distributed under the Creative Commons Attribution License, which permits unrestricted use, distribution, and reproduction in any medium, provided the original work is properly cited.

\begin{abstract}
With enrollment in the fields of science, technology, engineering, and mathematics (STEM) shrinking, teachers are faced with the problem of appealing to a new generation of students without sacrificing educational quality. Evidence has shown that this problem can be reduced with the use of a number of pedagogical strategies of which project-based learning (PBL) is one. PBL addresses the fundamental challenge of increasing students' motivation, their mastery of course material, and finding applications for what they have learned to apply in various situations. This study demonstrates the benefits of redesigning a standard lab-based molecular biology course to create a more effective learning environment. Using PBL, students who enrolled in Bio-251 at Harold Washington College in Chicago were given the responsibility of cloning a bacterial gene from one species into a new host species. They were then tasked with the expression and purification of the resulting protein for future research purposes at University of Illinois-Chicago, a leading 4-year research institute. With use of the PBL method, students showed improvement in the areas of self-confidence, lab technical skills, and interest in STEM-related fields and, most of all, the students showed a high level of performance and satisfaction.
\end{abstract}

\section{Introduction}

In 2003, the National Research Council suggested that opportunities for gaining a greater understanding of science could be realized through project-based laboratory courses [1]. Project-Based Learning (PBL) allows students to work actively with the applied techniques of the laboratory setting, while incorporating critical thinking, collaboration, and problem solving skills in the context of content-based knowledge that influences comprehension and academic selfconfidence. This method also benefits students by granting them accountability for laboratory projects, an approach that yields a deeper understanding of how science is practiced by scientists through problem solving and the formulation and testing of a hypothesis-based research [2]. This fundamental understanding is a direct byproduct of the project-based learning method.

In this study, we intend to highlight the outcomes of transforming a standard molecular biology course in a community college into a more effective learning experience using project-based learning. This is simply because projectbased learning utilizes both the tactile and visual senses to create a more complete learning experience, one that proves crucial in promoting the growth of STEM program enrollments [3]. Such a system would allow for a greater majority of students already enrolled in STEM courses to promote its success.

With career opportunities in STEM fields expected to increase $22 \%$ by the year 2014 [4], these fields are going to need even more highly skilled graduates to keep pace with the demand. Educators must rise to the challenge of identifying and addressing the shortcomings of classic teaching models to create an optimized curriculum and pedagogy that better suits today's students and helps meet the needs of today's societies. Fortunately, this transition is aided by the growing amount of research that has been conducted on how students learn. This research brings new insights on how to better educate the researchers of tomorrow for both academic and professional development. 


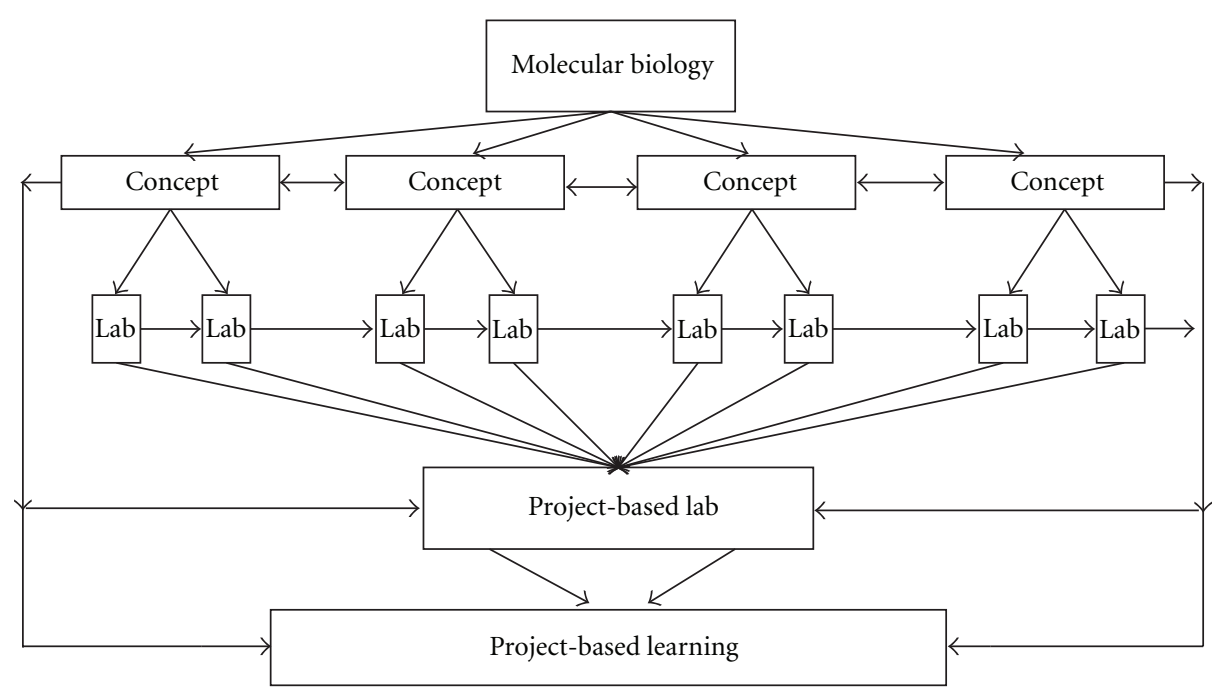

FIgURE 1: Concept map for project-based learning.

After all, as Cox et al. [5] argued, conveying facts does not alone produce scientifically literate students. Today's students of science need "a better window on what science is and how it is done, a clear presentation of key concepts that rises above the recitation of details, an articulation of philosophical underpinnings of the scientific discipline at hand, exercises that demand analysis of real data, and an appreciation for the contributions of science to the well-being of humans throughout the world" (p. xxi). We believe that by its nature, PBL can provide the opportunity for students to achieve just that.

\section{Methods and Materials}

Bio-251 is an introductory molecular biology course and one of the main courses in the biotechnology certificate program at Harold Washington College (HWC) in Chicago. The course had been experiencing low enrollment and retention rates and, in the term of our study, had been scheduled to meet once a week on Fridays from 4:15 to 9 p.m., not a time most students want to spend at school.

Typical introductory molecular biology courses at 2-year colleges often contain a sequence of topic-based lectures and various weekly laboratory assignments. The assignmentbased labs are often directed by a manual containing a generic set of assignments tailored to introduce several, often unrelated, techniques. Although students may enjoy learning new techniques, they fall short in understanding how the individual techniques are applied in professional scientific investigations. Furthermore, the connection between the knowledge and the applications is often not clearly made.

Based on realizations such as these, the Bio-251 course was redesigned to offer hands-on experience that is clearly made to be seen and applied by implementing the projectbased learning model with a single term-long group laboratory project. Figure 1 shows the concept-map of the relationship between learned concepts, weekly lab assignments, and the single term-long laboratory project. Other redesigned features included a number of quizzes, three exams, homework assignments, a weekly lab report, and a number of discussions/presentations. Lectures were designed with respect to the project in a way that would deliver theoretical knowledge and relevant information that students could immediately apply in laboratory learning and lab experiments. The first time the redesigned Bio-251 course was taught, fourteen students took part in this unique endeavor.

2.1. The Project. A unique project for the redesigned Bio-251 class at HWC was developed in collaboration with the nearby College of Pharmacy at the University of Illinois-Chicago (UIC). One of the interests of UIC was to clone a gene and express a protein to be used in medicinal chemistry research. Bringing this project to Bio-251 at Harold Washington College offered a wonderful opportunity for students to do a meaningful project in class through a project-based learning approach and under course supervision.

To truly understand the concept and successfully engage in the project-based learning approach, students need to know that if the first step is not performed properly, they cannot move on to the second one. For example, as seen in Table 1 and Figure 1, students must successfully complete the amplification of the gene before doing the ligation and transformation and so on. The premise was that the instructor's professional research experience in tandem with her teaching experience could provide this critical understanding to the students, while contributing something new to the scientific community.

2.2. Pedagogical Strategy and Rationale. In a typical biology laboratory, students usually follow the direction of a protocol, often with or without really understanding the concepts. Since the lab assignment they are doing is just one of many they have to complete during the semester, personal attachment is rare and boredom quickly follows. The students' focus shifts to getting the lab assignment over quickly and 
TABLE 1: Scheduled labs in Bio-251.

\begin{tabular}{|c|c|}
\hline Week & Scheduled labs \\
\hline 1 & $\begin{array}{l}\text { Basic laboratory safety techniques } \\
\text { Basic equipment and bacteriological techniques }\end{array}$ \\
\hline 2 & $\begin{array}{l}\text { Basic calculations for preparing solutions of different } \\
\text { concentrations }\end{array}$ \\
\hline 3 & Bacterial media prep, inoculation, and growth \\
\hline 4 & $\begin{array}{l}\text { Isolation of chromosomal DNA and preparation of } \\
\text { agarose gel }\end{array}$ \\
\hline 5 & PCR and agarose gel analysis \\
\hline 6 & $\begin{array}{l}\text { Restriction enzyme digestion, purification, and } \\
\text { preparation for cloning }\end{array}$ \\
\hline 7 & Ligation \\
\hline 8 & $\begin{array}{l}\text { Transformation } \\
\text { Making competent cells of } E \text {. coli and transforming the } \\
\text { recombinant plasmid. }\end{array}$ \\
\hline 9 & $\begin{array}{l}\text { Isolation of Plasmid, gel electrophoresis, and screening } \\
\text { for clone }\end{array}$ \\
\hline 10 & $\begin{array}{l}\text { Preparation for gene expression and transformation to } \\
\text { a suitable strain for expression }\end{array}$ \\
\hline 11 & Protein induction and expression \\
\hline 12 & Polyacrylamide gel electrophoresis \\
\hline 13 & Protein purification \\
\hline 14 & Protein purification troubleshooting \\
\hline 15 & $\begin{array}{l}\text { Bioinformatics (genome analysis, Blast, Primer3 for } \\
\text { designing PCR, Web-cutter) }\end{array}$ \\
\hline 16 & Computer analysis of the gene product \\
\hline
\end{tabular}

the main objective could easily be lost. In the redesigned Bio251 course, students were surprised to learn that there was no specific lab manual for the lab project. Instead, the students had access to a number of various lab manuals available in the class/lab, as well as on the Internet, that they could access any time before, during, or after a lab session. Students had to collaborate with each other and rely on each other for support in a problem-solving style, as opposed to reading a cookbook-style lab book with all of the answers neatly laid out. They were required to reflect on their experiences in the form of a lab report each week containing a short introduction, materials and methods, as well as results, and a conclusion. In the discussion section of each lab's conclusion, students had to identify how their results related to the results of previous labs and how these results might help them complete upcoming labs. In addition, students reported all of the problems they encountered in conducting the lab experiments and how they were able to deal with them.

After a few sessions, some of the students would go as far as to predict our next procedure in their conclusions. This was yet another indication that they were developing a deeper understanding of the concepts. Achieving success in each step brought joy and self-confidence to the students and promoted their enthusiasm for the course. Often, students mentioned that they could not wait for the next class meeting.

2.3. The Course at Work. Figure 1 shows the concept map of the course and how the various components of this course are related to each other. Concepts learned, weekly labs, projectbased labs, and how all of these elements lead to projectbased learning.

2.3.1. Topics and Concept Learned. Topics and concepts covered in this class included DNA \& RNA structure, DNA replication, bacteria and viruses as model organisms, transcription, translation, gene regulation, recombinant DNA technology and molecular cloning, polymerase chain reaction and its applications, and tools in molecular cloning: restriction enzymes, agarose gel analysis, usage of plasmids, tools for analyzing gene expression, genetically modified organisms, protein expression, protein purification, and an introduction to bioinformatics.

2.3.2. Weekly Lab Assignments. While the weekly lab assignments shown in Table 1 cover a basic molecular biology course, in Bio-251 each lab was designed and conducted with the goal of contributing to the completion of the projectbased lab that all of the students were involved in.

2.3.3. Project-Based Lab for Project-Based Learning. On the first day of the class, we introduced project-based learning to the students and explained its meaning, goals, procedures, and why they were going to be actively engaged in PBL instead of conducting the typical labs for a class like this. The first two weeks of the class focused on safety procedures, basic knowledge of bacterial culture, media and solution preparation, and proper usage of equipment (Table 1). At the beginning of each session, we discussed the theory and concepts behind the laboratory procedure of the week. Throughout the semester, students were given an optional bonus question, such as "What is the G/C ratio in the human genome?" At the end of every class session, we devoted time to discuss the relationship between the concept learned and the conducted lab, and identify the potential authentic contribution of the learned elements into the project-based lab.

After a few sessions, students began to take the initiative to start conversations with each other about the learned subjects, protocols, and lab procedures. These open discussions contributed to a higher level of understanding for almost all, as sharing of results allowed students to piece together their individual perspectives into a unified collective understanding through an authentic purpose. This method provided the opportunity for the students to clear up any confusion that could have potentially harmed their confidence. The method also helped students see the relevance of the information presented to them as it related to their own way of thinking, thus allowing them to make the connection between the subject matter, the lab project, and their own experiences.

At the end of each class, we spent 15 minutes on a laboratory briefing where we talked about how the lab experiments went, what types of problems were encountered (technical skills, conceptual knowledge, etc.), and how we solved them, as well as how we could use the outcomes of the lab experiments and the lab techniques in upcoming lab experiments. 


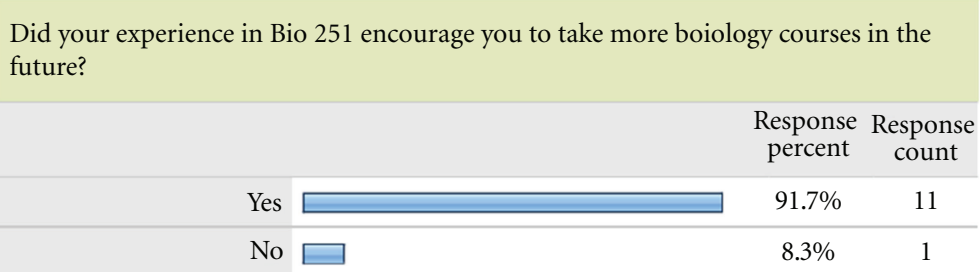

FIGURE 2: Survey Excerpt: The influence of the course on students' intention in taking more biology courses.

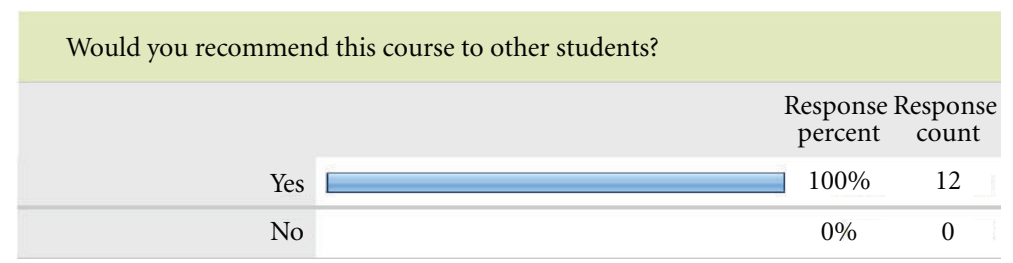

FIGURE 3: Survey Excerpt: Students' response on whether or not recommending the course to others.

Students indicated that this was a very useful experience for their cognitive development and helped build and develop their self-confidence.

On a few occasions we had to start certain procedures that had long processing times at the beginning of class in order to finish on time. The students did not receive the corresponding lectures and were just following protocols, very similar to a standard lab course. Unlike a standard lab, the students were exceedingly interested in what they were doing and how it fit into the big picture. They would ask so many questions that discussion had to be reluctantly limited in order to make the deadline. Since the entire course was focused around this project, the students' pronounced efforts to ensure their understanding indicated that the approach was working as intended.

2.3.4. Class Presentation. By mid-semester, students had to choose a topic related to the course and design a presentation using sources from peer-reviewed journals and review articles. Before the presentations were to begin, the students and the instructor discussed the basic elements of an effective presentation, and how important it was to be honest when evaluating one another. From these discussions came a rubric that the students used to grade each other's presentations. This enabled the presenter to receive valuable constructive criticism from multiple perspectives and the students watching had a good reason to pay attention. This approach also allowed for a lighter workload and more time to prepare for the class. The success of this method (which took all of 30 minutes to create) showed that even a routine task, like grading presentations, could be optimized for highefficiency learning.

2.3.5. Assessment of Student's Academic Performance. Student's academic performances were measured based on a number of quizzes, 3 exams, homework assignments, a weekly lab report, a number of discussions/presentations, and their contribution into the project-based lab.
2.4. Technical Outcomes. In our course, the project-based learning was a great success on many levels. Student success indicators chosen included the quality of their performance, satisfaction, and retention. Twelve of the fourteen students enrolled went on to successfully complete the course, ten of whom earned a B or higher. An anonymous survey was given three weeks after the course in which the students reported a high level of understanding, confidence and technical proficiency (Figures 1, 3, and 4). Students also reported that they felt encouraged to take more biology courses (Table 3 ) which demonstrates the course's ability to promote the growth of STEM courses.

At the pedagogical level, instead of wasting the material by doing unrelated labs and achieving marginal learning outcomes, students learned the subject matter and the lab techniques from an applied approach in which they embraced the project, cloned a gene, and expressed the protein. In the end, the project-based lab was completed with the highest technology at the lowest expense and made a new construct for future research purposes at UIC that was proudly named "pBio-251"! The students' satisfaction is confirmed by the fact that every one of them indicated that they would recommend this course to others (Figure 2).

\section{Survey Analysis and Explanation}

At the end of semester, a survey was given to the students which contained 10 questions. However, in this paper, we have only selected 6 questions that directly pertained to the topic of this paper.

Table 2 shows that when students were asked to rate various statements related to their own learning outcomes, the majority of them, (66.7\%), felt confident in their ability to perform the biotechnology lab procedures learned in the class. More than $80 \%$ of the students indicated that they understood the real world application of biotechnology lab procedures learned in the class. Furthermore, $75 \%$ of the students indicted that they gained an understanding of 
TABLE 2: Survey Excerpt: Students' reflections on their own learning outcomes.

\begin{tabular}{|c|c|c|c|c|c|c|c|}
\hline \multicolumn{8}{|c|}{ Please rate the following statements about your learning outcomes } \\
\hline & Strongly disagree & Disagree & Neutral & Agree & Strongly agree & Rating average & Response count \\
\hline $\begin{array}{l}\text { I am confident in my ability to } \\
\text { perform the biotechnology } \\
\text { procedures I learned from Bio- } 251\end{array}$ & $0.0 \%(0)$ & $8.3 \%(1)$ & $0.0 \%(0)$ & $25.0 \%(3)$ & $66.7 \%(8)$ & 4.50 & 12 \\
\hline $\begin{array}{l}\text { I understand the real world } \\
\text { application of the biotechnology } \\
\text { procedures I learned from Bio- } 251\end{array}$ & $0.0 \%(0)$ & $0.0 \%(0)$ & $8.3 \%(1)$ & $8.3 \%(1)$ & $83.3 \%(10)$ & 4.75 & 12 \\
\hline $\begin{array}{l}\text { I have gained insight on how } \\
\text { medical scientific research is } \\
\text { conducted }\end{array}$ & $0.0 \%(0)$ & $0.0 \%(0)$ & $0.0 \%(0)$ & $41.7 \%(5)$ & $58.3 \%(7)$ & 4.58 & 12 \\
\hline $\begin{array}{l}\text { I have gained an understanding of } \\
\text { the fundamental processes } \\
\text { involving the prokaryotic genome }\end{array}$ & $0.0 \%(0)$ & $0.0 \%(0)$ & $0.0 \%(0)$ & $25.0 \%(3)$ & $75.0 \%(9)$ & 4.75 & 12 \\
\hline
\end{tabular}

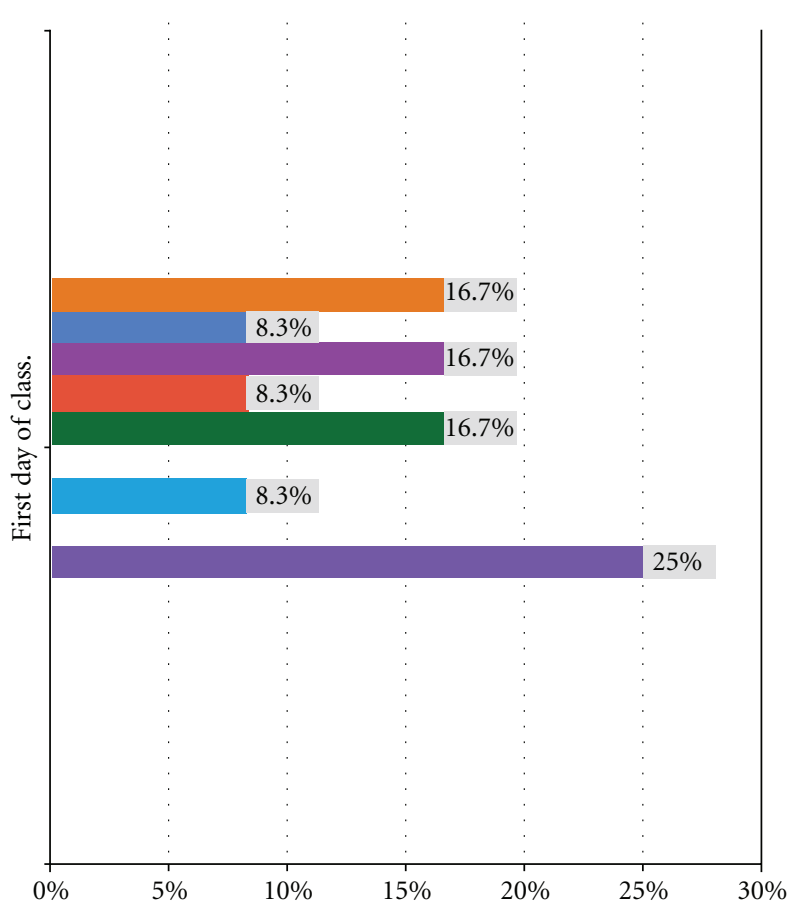

I do not know what biotechnology is.

- Series2

I could describe the methods of biotechnology.

- Series4

- I am familiar with the tools used in biotechnology.

- Series6

I can perform biotechnology procedures under supervision.

- Series8

I can perform biotechnology

procedures comfortably on my own.

- I invented biotechnology

FIGURE 4: Survey Excerpt: Students' perception of their own comfort with the biotechnology on the first day of the class. 
TABLE 3: Survey Excerpt: Student's reflection on the Bio-251.

\begin{tabular}{|c|c|c|c|c|c|c|c|}
\hline \multicolumn{8}{|c|}{ Please rate the following statements about the Bio-251 Course } \\
\hline & Strongly disagree & Disagree & Neutral & Agree & Strongly agree & Rating average & Response count \\
\hline $\begin{array}{l}\text { The course provided a } \\
\text { challenging learning } \\
\text { environment }\end{array}$ & $0.0 \%(0)$ & $0.0 \%(0)$ & $0.0 \%(0)$ & $8.3 \%(1)$ & $91.7 \%(11)$ & 4.92 & 12 \\
\hline $\begin{array}{l}\text { The course content was } \\
\text { focused and relevant }\end{array}$ & $0.0 \%(0)$ & $0.0 \%(0)$ & $0.0 \%(0)$ & $16.7 \%(2)$ & $83.3 \%(10)$ & 4.83 & 12 \\
\hline $\begin{array}{l}\text { I was encouraged to } \\
\text { research topics outside of } \\
\text { the classroom }\end{array}$ & $0.0 \%(0)$ & $0.0 \%(0)$ & $0.0 \%(0)$ & $16.7 \%(2)$ & $83.3 \%(10)$ & 4.83 & 12 \\
\hline $\begin{array}{l}\text { The course promoted } \\
\text { student collaboration }\end{array}$ & $0.0 \%(0)$ & $0.0 \%(0)$ & $0.0 \%(0)$ & $0.0 \%(0)$ & $100.0 \%(12)$ & 5.00 & 12 \\
\hline
\end{tabular}

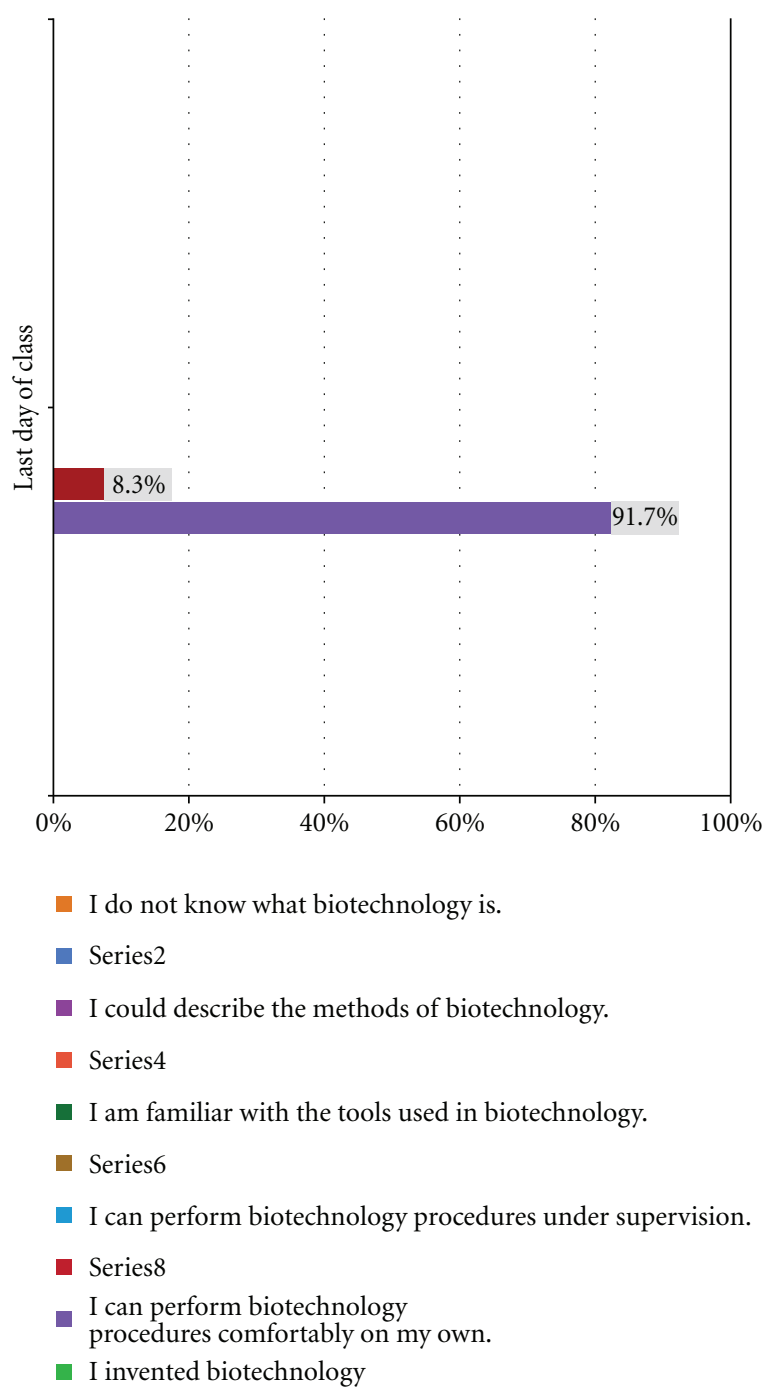

FIgURE 5: Survey Excerpt: Students' perception of their own comfort with biotechnology on the last day of the class.

the fundamental processes involving prokaryotic genome. Finally, more than half of the students (58.3\%) indicated that they had gained insight on how medical research is conducted.

Table 3 shows that when students were asked to rate various statements related to the course; all of the students
(100\%) indicated that the course promoted students' collaboration, both in and outside of the class. Furthermore, the majority of the students, $(91.7 \%)$, indicated that the course challenged them and provided a challenging learning environment that helped them to learn. In addition, more than $80 \%$ of the students indicated that the course content 
was focused and relevant to their learning, and the course and the learning environment encouraged them to research topics outside of the classroom.

Figure 2 shows that the majority of students, (91.7\%), indicated that the course encouraged them to take more biology courses.

Furthermore, as shown in Figure 3, all of the students indicated that they felt confident in recommending the course to other students.

Figure 4 shows that only $25 \%$ of the students indicated that they were comfortable in performing biotechnology procedures on their own at the beginning of the class.

Figure 5 shows the significant gains the students made in their confidence in describing the methods of biotechnology, and performing biotechnology procedures by the end of the course. While at the beginning of the semester only $25 \%$ of the students indicated that they were comfortable in performing biotechnology procedures on their own, by the end of the semester, this level of confidence had increased to $91.7 \%$. This increase is significant because it represents a $66.7 \%$ improvement in student confidence.

\section{Discussion and Conclusion}

Many educators would agree that the classic methods of teaching science is currently plagued by ineffective artifacts and thus is in dire need of modernization. While the facts delivered by the standard methods seldom change, the audience does. Even though certain students in each class can learn from the current methods, the rest of the students are too often weeded out, regardless of their innate talents. New methods of teaching are needed for the students of today, especially in STEM fields. The objective of promoting growth in the number of students enrolled in STEM programs is shifting from an advantage to a necessity in the modern world.

Project-Based Learning is a method in which students engage in intellectually challenging tasks that drive inquiry questions through gaining content knowledge and academic skills to solve complex problems and informatively defend their solution and outcomes. At HWC, project-based learning enabled the Bio-251 students to practice real world lab methods currently used in biotechnology, to comprehend the process of scientific inquiry that is practiced by working scientists, and to gain knowledge and demonstrate evidence of achievement. Learning research skills through practical experience is one of the main objectives of the project-based learning method, which has been supported by the NSF [6] and the NRC [7]. The individual experience of utilizing the laboratory stimulates increased excitement, knowledge, and confidence in performing applied scientific procedures. Important conceptual connections are made between critical thinking and practical applications through student learning on specifically designed projects. Throughout the semester, the class developed a good rapport that allowed them to work through and troubleshoot labs together, effectively changing the instructor's role from teacher to mentor. The students consistently worked together to overcome the obstacles encountered in class, many of which are issues encountered by professional scientists, as one student stated

\begin{abstract}
The overall mood and environment of this course were unlike anything I had previously experienced. At first, I was wary about taking a 5-hour course on Friday evenings, but when coupled with the casual structure and team emphasis, it felt more like getting together with friends to work on a hobby project than a molecular biology project. The sessions were highly productive and when something did go wrong, we were able to call for a time-out to discuss, we were quick to diagnose, and there was never a shortage of volunteers to help keep things moving.
\end{abstract}

The team-oriented environment is further supported by the survey (Table 2). It is apparent that very few, if any, of these Bio-251 students will forget this experience. Students were able to understand the concepts presented to them, while at the same time contribute valuable data and insight for research at UIC and for the world of molecular biology. Furthermore, some of the students started seriously thinking about continuing their education beyond the associate degree level.

\section{Acknowledgments}

The authors would like to thank Mr. William Thompson for his technical assistance; Dr. Maris Roze and Dr. Abour Cherif for helpful discussion and critically reading the paper and providing comments, and the all the students of Bio-251 (Section Z, Spring 2011) from Harold Washington College who participated actively in this study. The Biotechnology Program at HWC was funded by the Advanced Technological Education (ATE) of the National Science Foundation (NSF), grant no. 0903067. They also would like to acknowledge SENCER for the subaward from DUE/NSF, grant no. 0717407.

\section{References}

[1] D. J. Treacy, S. M. Sankaran, S. Gordon-Messer et al., "Implementation of a project-based molecular biology laboratory emphasizing protein structure-function relationships in a large introductory biology laboratory course," CBE Life Sciences Education, vol. 10, no. 1, pp. 18-24, 2011.

[2] P. Brickman, C. Gormally, N. Armstrong, and B. Hallar, "Effects of inquiry-based learning on students' science literacy skills and confidence," International Journal for the Scholarship of Teaching and Learning, vol. 3, no. 2, pp. 1-22, 2009.

[3] W. Ketpichainarong, B. Panijpan, and P. Ruenwongsa, "Enhanced learning of biotechnology students by an inquirybased cellulase laboratory," International Journal of Environmental and Science Education, vol. 5, no. 2, pp. 169-187, 2010.

[4] GAO, Higher Education, Federal Science, Technology, Engineering, and Mathematics Programs and Related Trends: A Report to the Chairman, Committee on Rules, House of Representatives, GAO Highlights, United States Government Accountability Office, 2005, GAO-06-114. 
[5] M. M. Cox, J. A. Doudna, and M. O’Donnell, Molecular Biology: Principles and Practice, W.H. Freeman and Company, New York, NY, USA, 2012.

[6] NSF, Shaping the Future: New Expectations for Undergraduate Education in Science, Mathematics, Engineering, and Technology, National Science Foundation, Arlington, Va, USA, 1996.

[7] NRC, Transforming Undergraduate Education in Science, Mathematics, Engineering, and Technology, National Academy of Sciences, Washington, DC, USA, 1999. 


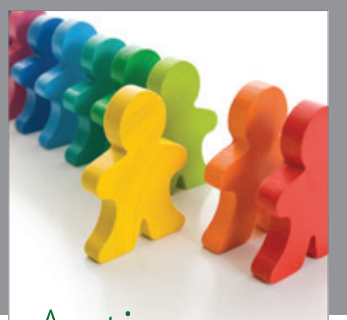

Autism

Research and Treatment
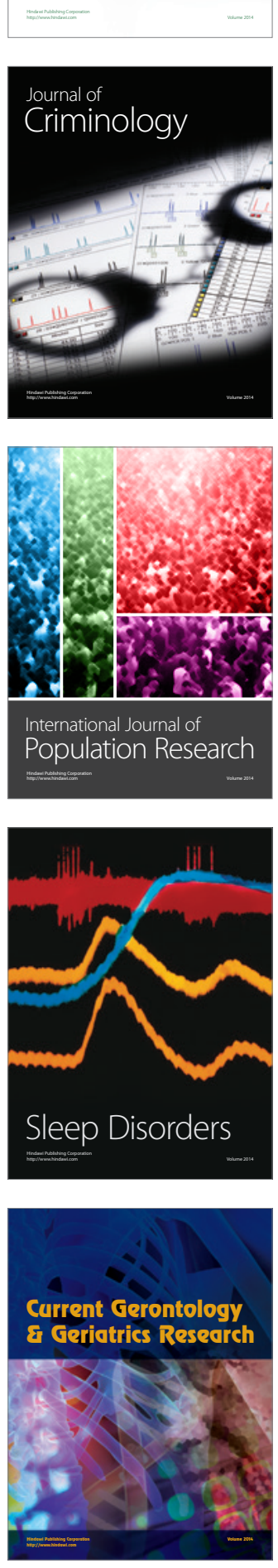
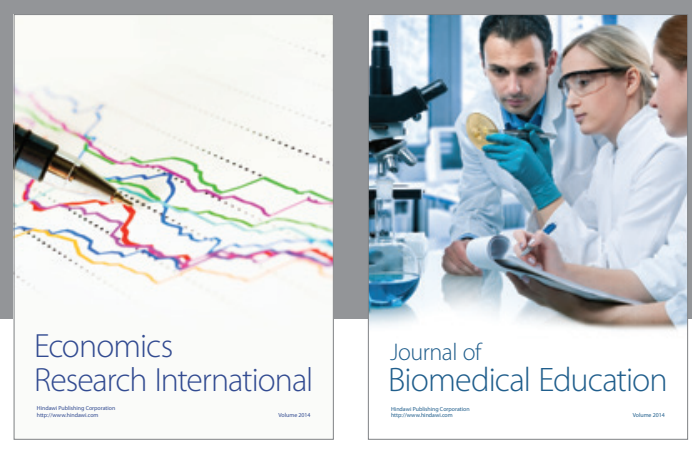

Journal of

Biomedical Education

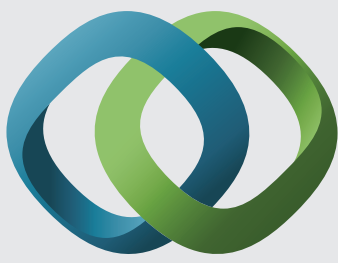

\section{Hindawi}

Submit your manuscripts at

http://www.hindawi.com
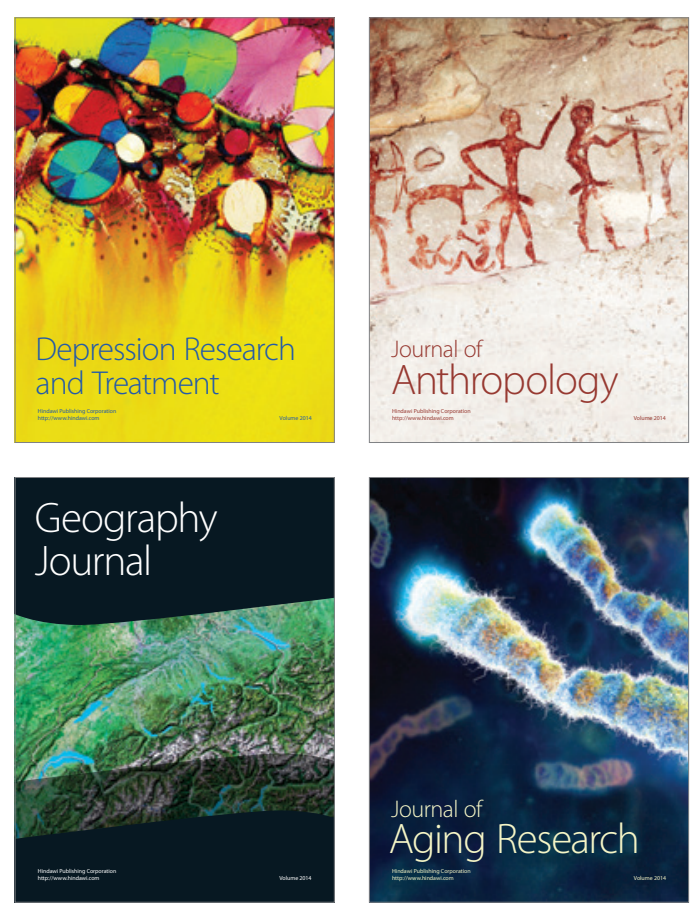

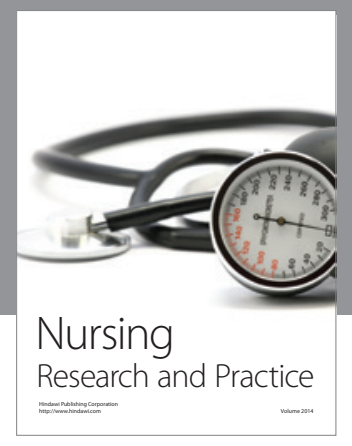

Nursing

Research and Practice

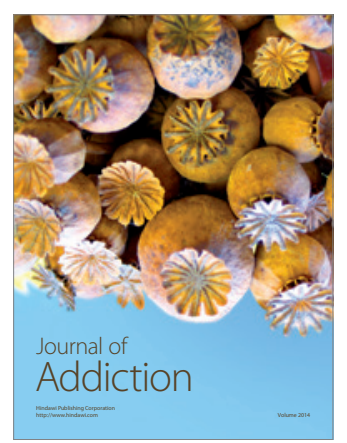

Child Development

Research

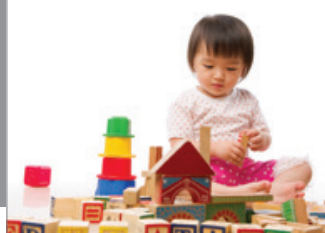

迥
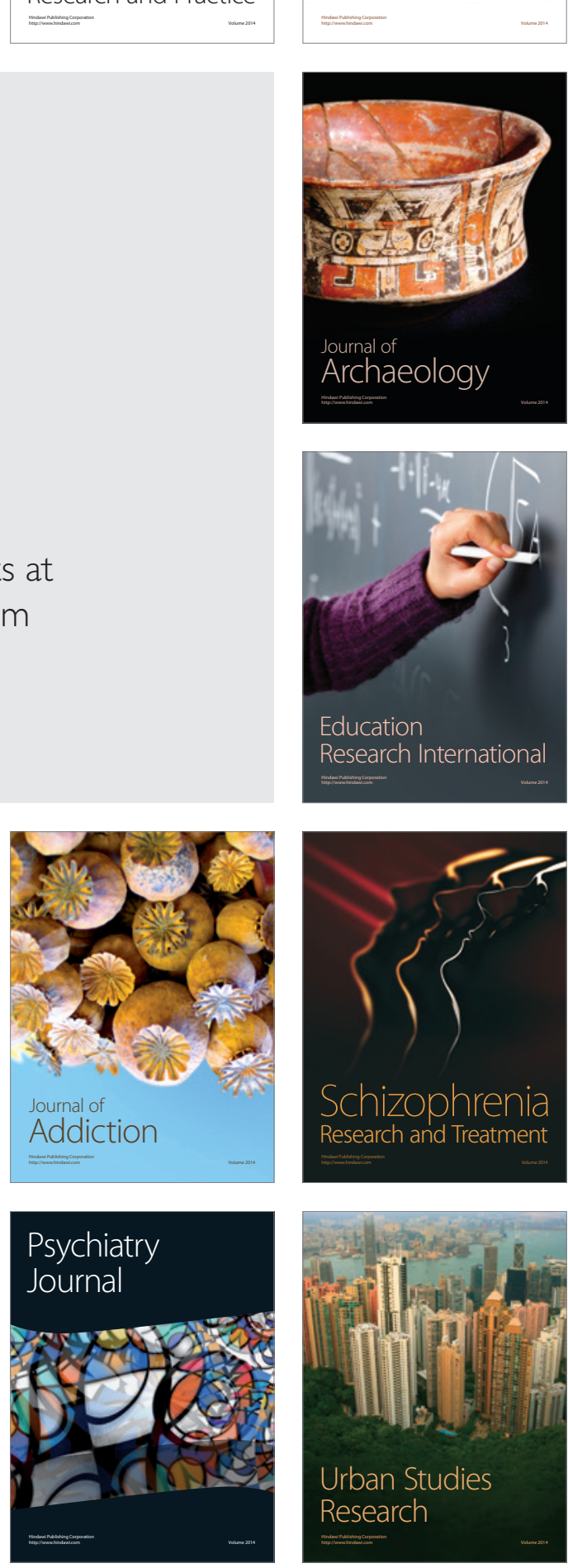